\title{
Equilibrating Internal and External Quality Assurance in Islamic Higher Education
}

\author{
Elis Ratna Wulan* \\ Mathematics Department, Science and Technology Faculty \\ UIN Sunan Gunung Djati Bandung \\ Bandung, Indonesia \\ *elis_ratna_wulan@uinsgd.ac.id
}

\author{
Syamsudin \\ Development of Islamic Societies Department, Da'wah and \\ Communication Faculty \\ UIN Sunan Gunung Djati Bandung \\ Bandung, Indonesia
}

\author{
Dindin Jamaluddin, Saca Suhendi \\ Islamic Education Department, Tarbiyah and Teacher Training Faculty \\ UIN Sunan Gunung Djati Bandung \\ Bandung, Indonesia
}

\begin{abstract}
This study aims to equilibrate accountability and improvement orientation of quality in Islamic Higher Education using the integrated approach as the best model. The study thus attempts to explore the relationship between internal and external quality assurance systems. The study employed descriptive statistics strategy and document analysis to aid the study answer the research questions. The finding of the research proposes that an integrated approach to quality assurance should be appropriately aligned with the need for Islamic Higher Education to have control over the internal quality process. The need for the governance structure of the internal and external quality system would be integrated on a common platform that promotes accountability, responsibility, and latitude.
\end{abstract}

Keywords-accountability, external quality assurance, integrated approach, internal quality assurance

\section{INTRODUCTION}

Indonesia upholds two training frameworks that are strict instruction under the Ministry of Religion's protection and state-funded instruction under the Ministry of National Education and Culture and the Ministry of Research, Technology, and Higher Education [1]. Generally, the Department of Religion directs all training degrees from youth instruction to Higher Education in Religion (Islam, Christianity, Catholicism, Hinduism, or Buddhist Higher Education). In the public training framework, strict instruction is a sub-framework [2], precisely after the authorization of Laws No. 22/1999 and No. 12/2008, strict instruction is excluded from self-sufficiency [3]. As a sub-framework, strict training administration is not left to neighborhood governments [4] yet oversaw straightforwardly by the focal government through a few units in the standard and regional authorities that are done underneath it [5].
Since the issuance of state strategy on the public instruction framework, the sub-framework has drawn nearer and has appended to the public training framework. In this manner, the contrast between the two frameworks, assuming any, is just identified with the strict training's terminologies. Here, statefunded instruction is known as school or Higher Education, while strict training utilizes another name, such as Islamic allinclusive school [5].

In particular, strict instruction is doled out to examine and extend comprehension of strict examinations. By the by, interconnection is bit by bit entwined with science. It connects the connection between strict and non-strict information. As a rule, study programs that carry them closer to the requests of work are more attractive. Therefore, it triggers serious rivalry between Higher Education because a similar report program is not just opened in Higher Education in Religion, yet additionally in General Higher Education [6]. These days, probably the most significant test in Higher Education is globalization, which has set off the improvement of the idea of cosmopolitanism for the sake of public autonomy and equity. The idea expects to shield worldwide understudies who originate from different nations, religions, societies, customs, and perspectives [7]. To satisfy this idea, HR, logical joining structures, offices and foundations, data innovation, internationalization, and universal collaboration in Religious Higher Education will be significant [8].

The execution of value affirmation in Higher Education turns into a pivotal activity to settle the distinctive characteristics and lobby qualified Higher Education dispersion. In any case, the execution of the Higher Education quality affirmation despite everything relies upon the administration's dedication [9], while the State is available to build up law authorization [5]. The quality affirmation framework is a pattern set off by global and transnational 
associations to guarantee that they get and produce an item that procures quality dependent on the guidelines they have concurred [10]. In light of the correlation of principles and the usage of value confirmation in numerous nations, there are similitudes in a structure and guidelines, albeit a few varieties are remembered for outside accreditation framework, especially the issue of the degree to which the consequences of the quality affirmation framework can remotely be utilized as an assurance for an inward quality norm in Higher Education. Thus, the results are valid among the general population, at the public level, and at a worldwide level [11]. In any case, the examples of value affirmation have likenesses in how its guidelines are arranged and are interpreted in Higher Education and how it changes the Higher Education Agency [12]. In the cycle, the developing issue a Higher Education is confronting is how to discover approaches to decipher the issue of value confirmation into its administration, so its missions are reflected in its instructing, exploration, and network administration. The quality affirmation guarantees the usage of the fundamental Higher Education, advancing science through examination and instructing. A coordinated way to deal with quality affirmation ought to be appropriately lined up with the Islamic Higher Education requirement to have power over the interior quality cycle. The requirement for the administrative structure of the inside and outside quality framework would be coordinated on a typical stage that advances responsibility, obligation, and scope.

The quality confirmation framework in Indonesia is not, at this point, debatable. The administration gives a public norm as a base norm for every Higher Education, while the Higher Educations themselves are offered chances to embrace principles over the public norm. In the pattern of a quality affirmation framework, they are additionally permitted to improve their quality on a progressing premise. The inner quality improvement, for example, is conveyed to deliver continuous improvement and to guarantee that the inside cycle functions admirably and is qualified [13]. Meanwhile, the outer quality confirmation, otherwise called accreditation, is a cycle of value approval. In Indonesia, both interior and outside, quality affirmation is applied to contemplate program levels or advanced education organizations [14]. In particular, quality depends on principles, rules, or instruments mutually planned and built up by the enthusiastic individuals about the accreditation. The detailing of instruments alludes to the norms created by the National Education Standards Agency that is therefore supported by the Minister of Research, Technology, and Higher Education - who in the advancement includes - the individuals who will end up being the surveyed gatherings and partners, including graduate clients [15].

This study attempts to explore the relationship between internal and external quality assurance systems and equilibrate accountability and improvement orientation of quality in Islamic Higher Education using the integrated approach as the best model.

\section{NATIONAL ACCREDITATION BOARD FOR HIGHER EDUCATION: EXTERNAL QUALITY ASSURANCE}

The National Accreditation Board endorses the authority to conduct accreditation in Indonesia for Higher Education. In practice, accreditation was introduced to the public through the establishment of the National Accreditation Board for Higher Education in 1994, which started the first accreditation in 1996. In 1998, the Government of Indonesia, through the Decree by the Minister of Education and Culture No. 187/U/1998, August 7, 1998, established the National Accreditation Board for Higher Education to respond to society's development in demanding the implementation of Higher Education quality assessment more efficiently and effectively. According to the Decree by the Minister of Education and Culture No. 28/2005, December 26, 2005, the Board is established not only to determine the feasibility of the program and (or) education unit and quality assurance in Higher Education but also to promote Higher Education accreditation as a form of public accountability [15].

As a follow up to the Law, the Minister of Education and Culture has issued Decree No. 87/2014, which is then amended by the Decree by the Ministry of Research, Technology, and Higher Education No. 32/2016 on Study Programs and Higher Education Accreditation. The Decree is used to regulate the Study Program Accreditation, and the Higher Education Institutions Accreditation run. Since 2008, although it was not mandatory, the National Accreditation Board for Higher Education has mainly undertaken accreditation in Higher Education Institutions

The latest encouraging development is the Decree by the Ministry of Research, Technology, and Higher Education No. 44/2015 concerning the National Standards for Higher Education, which has been issued and has amended the Decree by the Minister of Education and Culture No. 49/2014. According to the Decree by the Ministry of Research, Technology, and Higher Education No. 44/2015, the National Accreditation Board for Higher Education has even formulated a new instrument for Study Program Accreditation and Higher Education Institutions Accreditation, which have been continuously promoted to stakeholders and is eventually applicable [15].

\section{INTERNAL QUALITY ASSURANCE IN THE FORM OF INTERNAL QUALITY AUDIT}

Such reassuring advancement is the result and the acknowledgment of open responsibility. The Law No. 12/2012, Article 51-53 on Higher Education, for example, refers to that the Internal Quality Assurance framework is built to make qualified Higher Education in creating graduates or yields who can effectively build up their latent capacity and to create information or the potential to deliver advances that are helpful to society, country, and state. Put another way, creating graduates who have capacities become the catchphrase in it. To ensure the nature of the graduated class, Higher Education or Study Programs are needed to manufacture their Internal 
Quality Assurance framework effectively. In any case, Higher Education interior quality confirmation alludes to the National Standards for Higher Education. To acknowledge the Internal Quality Assurance framework has been actualized as requested by the National Standards for Higher Education, the examination programs and Higher Education organizations will, at that point, be authorized by the National Accreditation Board for Higher Education.

Moreover, the National Accreditation Board for Higher Education is the National Accreditation System in Indonesia and is generally known as the External Quality Assurance framework. In the Decree by the Minister of Education and Culture, No. 49/2014, the External Quality Assurance framework is a correlative aspect of the Internal Quality Assurance framework. The Higher Education quality confirmation through the Internal Quality Assurance framework will give a decent commitment to the External Quality Assurance framework. The Study Programs and Higher Education organizations must offer quality assistance to partners with right and legitimate inward quality affirmation frameworks. Quality will enhance a progressing premise as constant improvement, not just animated and started by the Ministry of Research, Technology, and Higher Education that surveys the public quality norm for Higher Education, yet additionally impacted by the Higher Education itself. The Study Programs can support the organization in maintaining the self-rule of science, educational opportunity, and scholarly discussion, creating themselves as suppliers of scholarly or expert projects by the field of study in control added to their repertoire and taking an interest in persistently improving the general public's ethical quality with quality norms.

\section{EQUILIBRATING INTERNAL AND EXTERNAL QUALITY ASSURANCE: THE INTERNAL QUALITY ASSURANCE SYSTEM IMPLEMENTATION (STUDY CASE IN UIN SUNAN GUNUNG DJATI BANDUNG (2016 - 2018 PERIOD)}

The Internal Quality Assurance System usage is done by following the arranging (plan), execution (do), assessment (check), control, and principles improvement (activity) design. In 2016, another Quality Assurance Board was framed. By its fundamental obligation, the Quality Assurance Board completes an arrangement for The Internal Quality Assurance System by investigating the National Standards of Higher Education.

The Quality Assurance Board plans a rules program dependent on the National Accreditation Board for Higher Education, at that point mingles the rules and starts an affirmation on the usage of value-based projects pronounced by Rector and is trailed by all Deans and heads of study programs. The Internal Quality Assurance System execution, despite everything, alludes to the quality records that have been set, via doing an Internal Academic Quality Audit, which incorporates: 1) arrangement of Internal Academic Quality Audit structures, 2) appearance and 3) preparing of Internal Academic Quality Audit results from the information.
The Quality Assurance Board directs an Internal Academic Quality Audit utilizing quality guidelines set by the authority of UIN Sunan Gunung Djati Bandung. This example is executed to set up the re-accreditation of study programs. In particular, given the consequences of The Quality Assurance Board results in information preparing suggestions for every staff are as per the following: Ushuluddin, Sharia and Law, Tarbiyah and Teacher Training, Adab and Humanities, Da'wah and Communication, Science and Technology, Psychology, and Social and Political Sciences.

In light of the Internal Academic Quality Audit results over, the Quality Assurance Board encourages study projects to set up a review dependent on the National Standards of Higher Education, held in 2017 and past. Likewise, the Quality Assurance Board gives help to read programs in getting ready for the re-accreditation of the National Accreditation Board for Higher Education. The Quality Assurance Board keeps on endeavoring to improve the inner quality affirmation framework, and dependent on the conversation of the inward degree of the Quality Assurance Board and the examiners, for the 2017 review, it will concentrate on reinforcing the educational plan alluding to The Indonesian National Qualification Framework that must be employed.

In 2017, the duty to execute the educational program alluding to The Indonesian National Qualification Framework under the Minister of Higher Education Research and Technology Regulation Number 44/2015 concerning National Higher Education Standards. Along these lines, UIN Sunan Gunung Djati Bandung reacted by concentrating on the Internal Quality Audit in 2017 on the standard five types of the National Accreditation Board for Higher Education. The execution of the Internal Quality Audit 2017 is centered around examining the use of the standard 5 types of the National Accreditation Board for Higher Education in the investigation program. This movement intends to review the execution of the educational program dependent on The Indonesian National Qualification Framework. They are beginning from the planning to the execution of instructing and learning exercises and assessment. The reviewers dictate rules for the readiness of structures.

The Quality Assurance Board directs an Internal Quality Audit which is centered around inspecting educational program norms. It starts with the educational program arrangement measure, regardless of whether did by methods in the Indonesian National Qualification Framework educational program readiness rules (by changing under the report design) educational plan structure, educational program substance, and Indonesian National Qualification Framework educational program usage that alludes to principles and rules. The investigation program administrator follows the Internal Quality Audit report structure by what is done and is approved by the evaluators.

The consequences of the 2017 Internal Quality Audit are utilized as a benchmark to survey whether the examination program has done the Indonesian National Qualification 
Framework educational plan arrangement measure as indicated by guidelines or not, regardless of whether the investigation program has actualized the Indonesian National Qualification Framework educational program steadily or not. Study programs that have satisfied the guidelines are urged to keep up and keep on improving. Study programs that don't fulfill the guidelines are urged to complete the cycle of arrangement and application in stages as per the setup norms. These means were brought out through the 2017 Internal Quality Audit follow-up meeting.

The investigation programs that have satisfied the guidelines or surpass principles are urged to keep on improving the nature of the Indonesian National Quality Framework educational plan both regarding educational program substance and its execution in the learning and instructing measure. Study programs that have not satisfied the guideline are treated as quickly as time permits to catch up to satisfy the Indonesian National Quality Framework educational plan principles and apply them steadily. Moreover, the Quality Assurance Board leads a review dependent on the Directorate of Higher Education.

In 2018, the duty to apply the UIN Sunan Gunung Djati Bandung Quality Standards in a far-reaching structure. In the wake of quickening, the study program's improvement, accreditation, and educational plan application depend on the Indonesian National Qualification Framework. Arranging is done by reexamining the Quality Policy, Quality Standards, and Quality Manuals that have been there previously, at that point directing socialization of the amended quality principles to all workforce and study program pioneers in the UIN SGD.

Execution of Internal Quality Audit 2018 was completed by propelling UIN Sunan Gunung Djati quality guidelines by college pioneers, investigation projects, and units. The satisfaction of the Internal Quality Audit's self-assessment study program is utilized as material to evaluate the investigation program's status depending on the National Standard of Higher Education and its qualification.

The assessment is led through the Internal Quality Audit in 2018, utilizing built up quality principles. The aftereffects of 2018 show that most examination programs and related units have met UIN Sunan Gunung Djati quality guidelines; however, just a little segment can surpass these quality principles. The controlling has been booked toward the finish of the even semester 2018 (December 2018 to January 2019) will be completed observing the usage of suggestions from the aftereffects of Internal Quality Audit 2018, with the point that review programs that have surpassed quality guidelines can keep up their accomplishments even keep on improving at a superior stage. For study programs that do not fulfill quality guidelines will keep on being encouraged until they can satisfy the quality guidelines. Besides, it will keep on being blessed to receive the option to surpass the built-up quality principles.

UIN Sunan Gunung Djati Bandung is a strict Islamic establishment that ensures quality in advanced education, specifically training, examination, and network commitment.
To keep up the nature of these three viewpoints, since 2016 there has been an inner observing and assessment of the execution and accomplishment of value focuses in 6 territories: 1) instruction, 2) research, 3) network commitment, 4) foundation, 5) fund, and 6) the executives completed regularly [16].

The units in Higher Education should work synergistically and deliberately and work dependent on commonly concurred principles. Likewise, their quality pointers have been actualized and assessed persistently, and the consequences of the quality norms assessment are utilized as the reason for policymaking. Further, the PDCA cycle likewise applies to ASEAN University Networks (AUN) principles. At long last, the Religious Higher Education board has worked by the reliable quality administration, and quality has no long run since it is needed to, but since it has become a culture among Religious Higher Education organizations.

\section{CONCLUSION}

Alluding to the writing study, it inferred that the Religious Higher Education organizations have actualized a decent quality confirmation framework, have exhibited quality culture, and have known about that accreditation is not just significant for their notoriety yet more critically, it is where they can ensure their administrations for understudies and people in general. By the expanding of mindfulness on quality by the Higher Education and Religious Higher Education in Indonesia, they are not just needed to accomplish the public norms for Higher Education but, at the same time, are offered chances to embrace global principles. An incorporated way to deal with quality affirmation ought to be appropriately lined up with the Islamic Higher Education requirement to have command over the inside quality cycle. The requirement for the administrative structure of the inner and outer quality framework would be coordinated on a typical stage that advances responsibility, obligation, and scope.

\section{ACKNOWLEDGMENT}

The authors would like to thank UIN Sunan Gunung Djati Bandung for supporting this research.

\section{REFERENCES}

[1] B. Yatim and H. Nasuhi, "Membangun Pusat Keunggulan Studi Islam Sejarah Dan Profil Pimpinan IAIN Syarif Hidayatullah Jakarta 19572002 [The Development of the Center for Islamic Studies: History and the Profile of the Leadership in IAIN Syarif Hidayatullah Jakarta 1957 2002]." Jakarta: IAIN Jakarta Press, 2002

[2] K.A. Steenbrink, Pesantren, madrasah, sekolah: pendidikan Islam dalam kurun moderen. Lembaga Penelitian, Pendidikan dan Penerangan Ekonomi dan Sosial, 1986.

[3] Jalal and D. Supriadi, Reformasi pendidikan dalam konteks otonomi daerah. Diterbitkan atas kerjasama Depdiknas, Bappenas, Adicita Karya Nusa, 2001. 
[4] M.D. Yahya, "Posisi Madrasah Dalam Sistem Pendidikan Nasional Di Era Otonomi Daerah,” Khazanah J. Stud. Islam dan Hum., vol. 12, no. 1, 2017.

[5] Tim Penyusun, Pedoman Pemberian Rekomendasi BAN PT kepada Menteri Terhadap Pendirian LAM. Jakarta: Jakarta: Sekeretariat BAN PT, 2015.

[6] Nursyam, "Renaisans Pendidikan Tinggi Islam," Natl. Semin. Pap. Syarif Hidayatullah State Islam. Univ. Jakarta, 2010.

[7] C.E. George-Jackson, "The Cosmopolitan University: The Medium toward Global Citizenship and Justice," Policy Futur. Educ., vol. 8, no. 2, pp. 191-200, 2010.

[8] Tim Penyusun, Rencana Strategis Pendidikan Islam. Jakarta: Jakarta: Sekjen Kementerian Agama RI, 2015.

[9] S. Gumiandari, "Komitmen Pimpinan Dalam Pelaksanaan Penjaminan Mutu Perguruan Tinggi (Studi Kasus IAIN Syekh Nurjati Cirebon)," Holistik, vol. 14, no. 2, 2016.
[10] B. Stensaker, "Quality as Fashion: Exploring the Translation of a Management Idea into Higher Education," in Quality assurance in higher education, Springer, 2007, pp. 99-118.

[11] D. Billing, "International Comparisons and Trends in External Quality Assurance of Higher Education: Commonality or Diversity?," High Educ., vol. 47, no. 1, pp. 113-137, 2004

[12] D.F. Westerheijden, B. Stensaker, and M.J. Rosa, Quality assurance in higher education: Trends in regulation, translation and transformation, vol. 20. Springer Science \& Business Media, 2007.

[13] Tim Penyusun, Pedoman Sistem Penjaminan Mutu Pendidikan Tinggi. Jakarta: Jakarta: Direktorat Pendidikan dan Pembelajaran, 2014.

[14] Tim Penyusun, Sistem Penjaminan Mutu Pendidikan Tinggi (SPM-PT). Jakarta: Jakarta: Direktorat Jenderal Pendidikan Tinggi, 2010.

[15] Editorial Team of the Office of Quality Management, Guide to AUN Actual Quality Assessment at Programme Level. Bangkok: Bangkok, AUN Secretariat, 2.0, and 3.0, 2015

[16] Borang UIN Sunan Gunung Djati Bandung, 2019. Bandung, 2019. 